\title{
The Nature and Scope of the FCC's Regulatory Power in the Wake of the NextWave and GWI PCS Cases
}

\author{
Nicholas J. Patterson $\dagger$
}

The Federal Communications Commission ("FCC") is the administrative agency that oversees the use of the electromagnetic spectrum in the United States. In dealing with parties licensed to use the spectrum, the FCC plays two roles. First, Congress created the FCC in 1934 as a regulator with control of the spectrum. ${ }^{2}$ In this role, the FCC allocates licenses for use of the spectrum and oversees licensees' use of these licenses in order to prevent interference. ${ }^{3}$ Second, in 1993, Congress made the FCC a creditor by authorizing the FCC to conduct competitive auctions for nonbroadcast FCC licenses. ${ }^{4}$ Congress also instructed the FCC to ensure that as part of its auction plan, it reserved certain blocks of spectrum for qualified entities, including small businesses, and made available deferred payment plans on favorable terms.' These spectrum auctions have generated billions of dollars in revenue as wireless technologies have developed.

$\dagger$ A.B. 1996, The University of Chicago; M.Phil. 1997, Cambridge University; J.D. 2002, The University of Chicago.

1 Communications Act of 1934, Pub L No 101-239, 103 Stat 2131, codified at 47 USC $\S 151$ (1994).

2 See id. See also R.H. Coase, The Federal Communications Commission, $2 \mathrm{~J}$ L \& Econ 1, 1-12 (1959) (providing an overview of the early history of the FCC).

3 See 47 USC $\$ 307$ (a)(1) (1994).

4 See 47 USC § 309(j) (1994 \& Supp 1998) (authorizing the FCC to sell electromagnetic licenses for personal communications services to private companies by auction and specifying the design of such bidding and the governmental objectives auctions should seek to promote). The idea of auctioning licenses was proposed decades earlier by a student author in The University of Chicago Law Review in 1951. See Leo Herzel, "Public Interest" and the Market in Color Television Regulation, $18 \mathrm{U}$ Chi L Rev 802, 811 (1951) (arguing that competitive bidding and freedom to determine how to use the radio spectrum is consistent with an economy organized around free consumer choice). In the late 1950s, Ronald Coase also championed auctioning licenses. See Coase, The Federal Communications Commission, $2 \mathrm{~J} \mathrm{~L} \&$ Econ at 20-24 (cited in note 2) (recommending auctioning of the radio spectrum).

5 See 47 USC \& $309(j)(4)(D)$ (requiring the FCC to design a competitive bidding methodology to "ensure that small businesses, rural telephone companies, and businesses owned by members of minority groups and women are given the opportunity to participate in the provision of spectrum-based services").

6 See Jill Carroll, Airwaves Auction Pulls in $\$ 16.68$ Billion, Wall St J B4 (Jan 29, 2001) (detailing profits generated by FCC spectrum auctions); Reuters, Airwaves Sale Sets Record, $\$ 16.86$ Billion, NY Times A10 (Jan 27, 2001) (noting that competitors bid in the billions for the "coveted" licenses). The licenses sold at these auctions are generally viewed as similar to leases to use a segment of the spectrum for a specified amount of time. See Thomas W. Hazlett, Assigning Property Rights to Radio Spectrum Users: Why Did FCC License Auctions Take 67 
When a licensee goes bankrupt, tension arises if the FCC tries to use its position as a regulator to give it an advantage as a creditor. The question is whether courts should treat the FCC as a creditor or as a regulator in Chapter $11^{7}$ bankruptcy proceedings involving electromagnetic spectrum licensees. The FCC's dual role has led the Second, Fifth, and D.C. Circuits to reach different and conflicting conclusions regarding the scope of the FCC's regulatory power in such proceedings.

The courts' efforts to reconcile the FCC's roles are made difficult because of tension between a primary goal of bankruptcy and the Bankruptcy Code's deference to governmental units acting in their regulatory capacities. One of the main purposes of bankruptcy is to create an orderly proceeding that avoids a race to the courthouse, which could destroy the value of the bankruptcy estate. ${ }^{8}$ The Bankruptcy Code provides an automatic stay to fix this creditors' collective action problem.' The stay gives the debtor's assets a safe harbor." However, the Code also prevents courts from enjoining a governmental entity's exercise of regulatory power."

Years?, 41 J L \& Econ 529, 532 n 8 (1998) ("License rights ... allow the licensee to access certain frequencies using certain types of equipment to provide certain types of service-as regulated by the commission. Hence, the licenses are not 'spectrum rights' but 'use permits."). See also Evan R. Kwerel and John R. Williams, Changing Channels: Voluntary Reallocation of UHF-TV Spectrum, Working Paper No 27 (FCC Office of Plans and Policy Nov 1992); John O. Robinson, Spectrum Management Policy in the United States: An Historical Account, Working Paper No 15 (FCC Office of Plans and Policy Apr 1985); Stephen Labaton, Clinton Orders a New Auction of the Airwaves, NY Times A1 (Oct 14, 2000) (describing how President Clinton ordered the federal government to auction off spectrum previously controlled by government agencies to decrease growing congestion of the airwaves).

7 See Bankruptcy Reform Act of 1978, HR Rep No 95-595, 95th Cong, 1st Sess 343 (1977), reprinted in 1978 USCCAN 6179-80 (stating that the purpose of a Chapter 11 business reorganization case, unlike a Chapter 7 liquidation case, is "to restructure a business's finances so that it may continue to operate, provide its employees with jobs, pay its creditors, and produce a return for its stockholders").

8 When businesses encounter financial distress, creditors often rush to collect debts out of fear that if the business fails they will be left with nothing. Both debtors and creditors suffer if this rush is allowed. Debtors are hurt because their assets are often worth less when sold piecemeal and because they have less of a chance of retaining their businesses and assets. Creditors are injured because only those creditors who win the race are paid, while creditors who call their debts later end up with nothing. See Douglas Baird, The Elements of Bankruptcy 168 (Foundation $3 \mathrm{~d}$ ed 2001) (noting that creditors "are not indifferent between being paid now or being paid later" because they recognize that the debtor may become insolvent before paying his debts).

911 USC \& 362(a) (1994).

10 Under Title 11, the general rule is that bankruptcy petitions automatically invoke a stay against creditors. This stay prevents them from collecting on the debts owed to them by the debtor. In addition, the automatic stay allows the debtor-in-possession to deal with all of its creditors in the single forum of the bankruptcy court. See Baird, The Elements of Bankruptcy at 17-18 (cited in note 8) ("As a practical matter, one of the debtor's most important rights in Chapter 11 may be its exclusive right to propose a plan of reorganization.").

1111 USC \& 362(b)(4) (1994) (stating that the automatic stay does not apply to "the commencement or continuation of an action or proceeding by a governmental unit ... to enforce 
The current circuit splits arose out of the FCC's auctioning of the C-block of the spectrum, a segment it had reserved for small businesses and for whose licenses it allowed winning bidders to pay using deferred payment plans. The FCC concluded two sets of C-block auctions on May 6 and July 16, 1996. In early 1997, a significant number of C-block licensees petitioned the FCC for relief from their installment payments because they had financing difficulties and faced the prospect of early default. ${ }^{13} \mathrm{~A}$ number of these licensees subsequently filed for Chapter 11 bankruptcy. ${ }^{14}$ The FCC declared the licenses canceled and attempted to re-auction them. The licensees in bankruptcy challenged the FCC's decision.

Two of the licensees who filed for Chapter 11 bankruptcy encountered three different results at the appellate level regarding the jurisdiction of the FCC in licensee bankruptcy proceedings. ${ }^{\text {1s }}$ In In re NextWave Personal Communications, Inc, ${ }^{16}$ the Second Circuit viewed the FCC as a regulator whose regulatory actions did not fall under the jurisdiction of bankruptcy or district courts. ${ }^{17}$ The Second Circuit reaffirmed this view in In re Federal Communications Commission.

such governmental unit's ... police or regulatory power").

12 The C-block is a section of the electromagnetic spectrum the FCC divided into 493 licenses and reserved to auction to small entrepreneurial companies providing personal communications services ("PCS"). PCS is a new generation of wireless-phone technology that provides the user with an all-in-one wireless phone, paging, messaging, and data service. See 47 CFR $\$ 24.709$ (1995) (discussing PCS).

13 In re GWI PCS Inc, 230 F3d 788, 793 (5th Cir 2000).

14 David A. Montoya, The FCC v. Powers of the Bankruptcy Courts: A Closer Look at NextWave and the Other C-Block Cases, 2001 ABI Jnl LEXIS 62, *3 (2001) (describing four bankruptcy cases involving C-Block licensees).

15 In addition, it seems likely that a fourth circuit split may develop within the next few months. The Tenth Circuit heard oral arguments in January in a case involving Kansas PCS, the winning bidder of three C-block licenses. Similarly to NextWave, Kansas PCS failed to make installment payments on licenses, which then cancelled automatically under Commission rules. The U.S. Bankruptcy Court ruled that the Bankruptcy Code precluded the Commission's automatic cancellation regulation from being enforced. In re Kansas Personal Communications Services Ltd, 252 BR 179, 195 (Bankr D Kan 2000). However, the U.S. District Court reversed this decision, ruling that the license cancellation was automatic and was not covered by section 362 of the Code. United States of America v Kansas Personal Communications Services, Ltd, 256 BR 807, 814 (D Kan 2000). Kansas PCS appealed this decision to the Tenth Circuit, arguing that the D.C. Circuit's decision in NextWave calls into question the action the bankruptcy court took in its own case. See Broad Array of Operators Awaits Certainty in NextWave Battle, Mobile Comm Report A1 (Jan 7, 2002). It is quite possible that the Tenth Circuit will hand down a decision in this case that will view the scope of the FCC's regulatory power in bankruptcy proceedings in a different way than the other three circuits that have weighed in on this issue.

$16200 \mathrm{F3d} 43$ (2d Cir 1999).

17 Id at 62 (holding that "the bankruptcy and district courts had no power to interfere with the FCC's system for allocating spectrum licenses").

18217 F3d 125, 128-29 (2d Cir 2000) (reaffirming that "the FCC's licensing decisions are subject to the exclusive jurisdiction of the federal courts of appeals"). 
In NextWave Personal Communications, Inc v FCC, ${ }^{19}$ the D.C. Circuit, examining an identical set of facts, reasoned that the FCC was a regulator subject to its jurisdiction under the Bankruptcy Code. ${ }^{20}$ In contrast, the Fifth Circuit in In re GWI PCS Inc, another case with almost exactly the same fact pattern as the Second and D.C. Circuits had confronted in the NextWave cases, held that bankruptcy and district courts had jurisdiction over the FCC in a bankruptcy proceeding involving a licensee.

These decisions have created a three-way circuit split concerning the nature and scope of the FCC's regulatory power in future bankruptcy proceedings involving licensees. Should the FCC be allowed to act as a regulator with whom the bankruptcy and district courts cannot interfere, or should it be treated as a creditor over whom these courts have jurisdiction?

This Comment argues that issues of jurisdiction in bankruptcy should turn on regulatory competence, and that making decisions in a bankruptcy proceeding is beyond the FCC's regulatory competence. Although the FCC's rules controlling the use of licenses should have effect in bankruptcy, the FCC, as an entity interested in collecting a fixed sum, should be considered an ordinary creditor in the bankruptcy process. Part I of the Comment explains the split between the Second, D.C., and Fifth Circuits. Part II analyzes the incompatibilities and tensions that prevail in the current state of the law. Part III briefly proposes a solution, namely, that the power of a regulatory agency in bankruptcy proceedings should be limited to its regulatory competence, and illustrates how this solution works in practice through a land use hypothetical. Part IV looks more closely at how this solution is supported by the Bankruptcy Code and shows how the solution can be applied to the FCC.

\section{THE THREE-WAY SPLIT OVER THE FCC'S JURISDICTION IN BANKRUPTCY PROCEEDINGS}

The Supreme Court has not yet addressed the issue of whether the FCC should be allowed to act as a creditor or a regulator in bankruptcy proceedings involving spectrum licensees. ${ }^{23}$ The closest the

19254 F3d 130 (DC Cir 2001).

20 Id at 155-56 (holding that because the FCC chose "a scheme that put it in a creditordebtor (and lienholder) relationship with its licensees," the Commission was subject to the provisions of the Bankruptcy Code).

21230 F3d 788 (5th Cir 2000).

22 See id at 803-04 (holding that the district court properly granted the debtor's motion to dismiss and noting that the FCC did not contend that the bankruptcy court lacked jurisdiction).

23 The Court denied certiorari in both Second Circuit cases, NextWave Personal Communications v FCC, 531 US 1029 (2000), and NextWave Personal Communications v FCC, 531 US 924 (2000), as well as in the Fifth Circuit case, United States v GWI PCS 1, Inc, 121 S Ct 2623, 2624 
Court has come was Board of Governors of the Federal Reserve System v MCorp Financial, Inc, where it faced the more general issue of what happens when a federal regulatory agency seeks to control a debtor's assets. ${ }^{25}$ Prior to filing for bankruptcy, MCorp induced two subsidiary banks to extend credit to an affiliate and entered into other transactions that may have violated federal banking law. ${ }^{26}$ The Board of the Federal Reserve ("Board") began two administrative proceedings: one before and another after MCorp had entered bankruptcy.

The Court held that the district court could neither review nor enjoin the Board's ongoing administrative proceedings. ${ }^{27}$ It rebuffed MCorp's assertion that the Board had violated the automatic stay by attempting to enforce a prepetition claim. Instead, the Court found that the Board's actions came under the regulatory power exception to the automatic stay found in Section 362(b)(4) of Title 11. It reasoned that "MCorp's broad reading of the stay provisions would require bankruptcy courts to scrutinize the validity of every administrative or enforcement action brought against a bankrupt entity." ${ }^{23}$ Such a reading is problematic, "both because it conflicts with the broad discretion Congress has expressly granted many administrative entities and because it is inconsistent with the limited authority Congress has vested in bankruptcy courts."

The Court also held that the proceedings might end in a final order that would impair the bankruptcy court's exclusive jurisdiction over property of the estate. ${ }^{30}$ However, the Board's actions were not in violation of the automatic stay until this occurred. ${ }^{31}$ The Court suggested that "it may well be proper for the Bankruptcy Court to exercise its concurrent jurisdiction under 28 USC $\S 1334(\mathrm{~b})$ " if the Board's proceedings were to culminate in a final order. ${ }^{32}$ Thus, the Supreme

(2001). However, the Court granted certiorari in NextWave v FCC, Federal Communications Commission $v$ NextWave Personal Communications, Inc, 122 S Ct 1202 (2002). Oral arguments will probably not take place until fall 2002 and it is unlikely that the Court will deliver a decision before early 2003. See Dreazan, Fight over NextWave Spectrum Moves to Supreme Court Docket, Wall St J B6 (Mar 5, 2002) (describing the Supreme Court's grant of certiorari in NextWave v FCC).

502 US 32 (1991).

Id at $40-41$.

See Baird, Elements of Bankruptcy at 176 (cited in note 8).

MCorp, 502 US at 44.

Id at 40 .

Id.

30 See MCorp, 502 US at 41.

31 Id. ("We are not persuaded ... that the automatic stay provisions of the Bankruptcy Code have any application to ongoing, nonfinal administrative proceedings."). See also Baird, Elements of Bankruptcy at 200-01 (cited in note 8) (discussing the Court's MCorp decision).

32 MCorp, 502 US at 41. See also 28 USC $\S 1334$ (b) ("Notwithstanding any Act of Congress that confers exclusive jurisdiction on a court or courts other than the district courts, the district courts shall have original but not exclusive jurisdiction of all civil proceedings arising under 
Court established boundaries, albeit murky, regarding the scope of a regulatory agency's power in bankruptcy proceedings: Regulatory agencies, under section 362(b)(4), are competent to control the actions of debtors, but bankruptcy courts have jurisdiction over the property of the debtor's estate.

To understand the current state of the law, it is necessary to carefully analyze the split among the Second, Fifth, and D.C. Circuits. The key distinction among the courts' holdings derives from their differing views on the FCC's role as either a regulator or a creditor.

\section{A. The Second Circuit's NextWave and FCC Decisions: The Bankruptcy and District Courts Do Not Have Jurisdiction over the FCC's Regulatory Actions}

This Part describes the two decisions of the Second Circuit involving NextWave: NextWave and FCC. Two decisions were necessary because on remand the bankruptcy court did not follow the instructions the Second Circuit gave in NextWave.

\section{The Second Circuit's NextWave decision.}

The Second Circuit reversed the bankruptcy court's decisions avoiding part of NextWave's debt to the FCC and allowing it to keep the licenses at a reduced price, holding that the bankruptcy court did not have jurisdiction over the FCC's cancellation of NextWave's licenses. ${ }^{33}$ The court made four main points. First, it found that the FCC's action was regulatory: The Commission "made 'full and timely

title 11, or arising in or related to cases under title 11.").

33 On June 8, 1998, NextWave filed for Chapter 11 bankruptcy protection in New York. See In re Nextwave Personal Communications, Inc, 235 BR 263, 267 (Bankr S D NY 1998) ("Nextwave I"). After a hearing, the bankruptcy court handed down five decisions and orders. In its first NextWave decision, the court asserted jurisdiction over the case because, in its opinion, NextWave's claim against the FCC did not relate to "any regulatory conduct on the part of the FCC," but instead concerned the debtor-creditor relationship between the FCC and Next Wave. See id at 269 (noting NextWave's first cause of action merely asserted that the alleged transfer executed by NextWave and transferred to the FCC exceeded the value of property received by NextWave).

After establishing jurisdiction, the court held that NextWave's winning bid was greater than the fair market value of the licenses at the time of conveyance, and avoided $\$ 3.72$ billion of NextWave's $\$ 4.74$ billion license fee obligation, thus reinstating the obligation only to the value actually given. See In re NextWave Personal Communications, Inc, 235 BR 277, 304 (Bankr S D NY 1999) ("NextWave III"). Under section 544(b), the trustee can avoid or "set aside transfers that a debtor makes, while insolvent, for less than reasonably equivalent value as well as any transfers that delay, hinder, or defraud creditors." See Baird, Elements of Bankruptcy at 101 (cited in note 8). Soon thereafter, the court decided the appropriate remedy and allowed NextWave to keep its license for the reduced price of $\$ 1.02$ billion. See In re NextWave Personal Communications, Inc, 235 BR 305, 311-13 (Bankr S D NY 1999) ("NextWave IV"). The district court affirmed all of the bankruptcy court's decisions upon appeal. In re NextWave Personal Communications, Inc, 241 BR 311,321 (S D NY 1999). 
payment of the winning bid' a regulatory condition for obtaining and retaining a spectrum license," and this condition had a purpose "related directly to the FCC's implementation of the spectrum auctions." ${ }^{\text {34 }}$

Second, the court held that the bankruptcy court lacked jurisdiction over the claim. Jurisdiction over claims brought against the FCC in its regulatory capacity lies exclusively in the federal courts of appeals. ${ }^{35}$ Thus, "the bankruptcy and district courts lacked jurisdiction to decide the question of whether NextWave had satisfied the regulatory conditions placed by the FCC upon its retention of the Licenses.".36

Third, the Second Circuit held that the bankruptcy court impaired the FCC's method for selecting licensees by "effectively awarding the Licenses to an entity that the FCC determined was not entitled to them." In so doing, it "exercised the FCC's radio-licensing function," which was something it was "utterly without the power" to do." The bankruptcy court meddled with the FCC's regulatory purpose by avoiding a large part of NextWave's bid price, thereby letting NextWave keep the licenses for a lower price. ${ }^{39}$

Lastly, the Second Circuit, despite finding that the bankruptcy court lacked jurisdiction to alter the conditions under which NextWave could keep its licenses, admitted that the bankruptcy court might have jurisdiction over NextWave's underlying debts. ${ }^{40}$ The Second Circuit noted that NextWave remained "a debtor in bankruptcy," and that "[i]f the Licenses [were] returned to the FCC, the bankruptcy court [might] resolve resulting financial claims that the FCC has against NextWave." ${ }^{, 11}$ Examining the merits of the bankruptcy court's

34 In re NextWave Personal Communications, Inc, 200 F3d 43, 52 (2d Cir 1999) (quoting 47 CFR $\S 24.708$ (1994)). The purpose was to make the FCC's default rules and penalties enforceable, "because the FCC relied upon them as a substitute for conducting the 'detailed credit checks' and other forms of due diligence that otherwise would be necessary to ensure ... that the licenses would be awarded to the appropriate entities." Id at 53, quoting In re Implementation of Section 309(j) of the Communications Act-Competitive Bidding, Second Report and Order, 9 FCC Rec 2348, 2382 (Apr 20, 1994).

35 See 47 USC $\S 402$ (b) (1994 \& Supp 1996) (stating that appeals from decisions and orders of the Commission may be taken to the D.C. Circuit in certain situations); 28 USC \$ 2342(1) (1994) (stating that the courts of appeals (other than the Federal Circuit) have exclusive jurisdiction to enjoin, set aside, or determine the validity of all final orders of the FCC reviewable under 47 USC $\$ 402(a)$ ).

36 NextWave, 200 F3d at 54 .

37 Id at 55 .

38 Id.

39 Id ("[E]ven if the bankruptcy and district courts were right in concluding that granting the Licenses at a small fraction of NextWave's original successful bid price best effectuated the FCA's goals, they were utterly without the power to order that NextWave be allowed to retain them for that reason or on that basis.") (citation omitted).

40 Id (explaining that the court has jurisdiction over those transactions that "do not touch upon the FCC's regulatory authority").

41 Id at 56. 
avoidance decision, the court held that the bankruptcy and district courts had no power to interfere, reversed the judgment of the district court, and remanded for further proceedings. ${ }^{42}$

Immediately after the Second Circuit reversal, NextWave proposed a new reorganization plan that provided for a lump-sum payment that would satisfy its whole 4.3 billion dollar outstanding debt to the FCC. The FCC protested against this plan, arguing that NextWave's licenses had automatically canceled when NextWave missed its first payment deadline in October $1998{ }^{43}$ The FCC also released a public notice announcing re-auction of NextWave's licenses. ${ }^{4}$

2. The Second Circuit's FCC decision.

The Second Circuit subsequently reversed a bankruptcy court ${ }^{\text {ts }}$ decision nullifying the FCC's cancellation of NextWave's licenses and reasserted the FCC's jurisdiction. ${ }^{46}$ It granted the FCC a writ of mandamus to enforce its holding in NextWave. The court stated: "The FCC need not defend its regulatory calculus in the bankruptcy court; whenever an FCC decision implicates its exclusive power to dictate the terms and conditions of licensure, the decision is regulatory .... [Therefore,] it may not be altered or impeded by any court lacking jurisdiction to review it." ${ }^{47}$ The Second Circuit concluded that the bank-

42 Id at 62.

43 See In re Pub Notice DA 00-49, Auction of C and F Block Broadband PCS Licenses, Order on Reconsideration, 15 FCC Rec 17500, 17504 II 5 (Sept 6, 2000) ("Pursuant to our Restructuring Orders, the $\mathrm{C}$ and $\mathrm{F}$ block licenses granted to NextWave canceled automatically on October 30,1998 because NextWave failed to make its payment by the resumption deadline of October 29, 1998."). See also NextWave v FCC, 254 F3d at 138 ("The Commission objected to the plan, alleging that NextWave's licenses had automatically cancelled when the company missed its first payment deadline in October 1998.").

44 See Public Notice, Auction of C and F Block Broadband PCS Licenses, 15 FCC Rec 693 (Jan 12, 2000):

[L]icenses for operation on frequencies as to which previous licenses have cancelled ... are available for auction under the automatic cancellation provisions of 47 CFR $\S 1.2110$ (f)(4)(iii)-(iv). The previous licensees were participating in the Commission's installment payment plan and were more than 90 days delinquent for the July 31,1998 resumption payment.

45 See In re NextWave Personal Communications Inc, 244 BR 253, 257-58, 267-68 (Bankr S D NY 2000) ("NextWave VI") (asserting jurisdiction and affirming a prior court order holding that the FCC's cancellation of NextWave's licenses was "null and void" as a violation of numerous provisions of the Bankruptcy Code, including the automatic stay provisions of section 362(a). The court, recognizing it lacked power to review FCC regulatory actions, id at 260-61, cast the dispute in nonregulatory terms. Id at 274 ("The FCC acted as a creditor, and ... not in any regulatory capacity."). It determined that the FCC's requirement of timely payment as a licensing condition lacked regulatory purpose, id at 270 , and held that the Second Circuit's previous decision did not preclude it from voiding the FCC's cancellation of NextWave's licenses, which was based on an asserted violation of that condition. See id at 283.

46. In re FCC, 217 F3d 125, 129 (2d Cir 2000).

47 Id at 135 (emphasis added). 
ruptcy court had violated the Second Circuit's instruction on remand in NextWave.

The court asserted that the automatic stay was limited by 11 USC $\S 362$ (b)(4), which provides an exception for a governmental unit that is seeking "to enforce" its "regulatory power." The Second Circuit refused to consider the bankruptcy court's determination on the merits of the case because it concluded that the bankruptcy court lacked jurisdiction. ${ }^{50}$ The court explained that under 47 USC $\$ 402$, exclusive jurisdiction to review the FCC's regulatory action "lies in the courts of appeals." "The Second Circuit thus concluded that the bankruptcy court "acted in derogation of this Court's mandate and beyond its statutory jurisdiction when it nullified the FCC's Public Notice."s2

B. The D.C. Circuit's NextWave v FCC Decision: The FCC Is Subject to the D.C. Circuit's Jurisdiction, and the FCC's Regulatory

Power Is Limited by the Bankruptcy Code

Upon losing in the Second Circuit, NextWave filed a petition with the FCC asking for reconsideration of the license cancellation. The FCC denied the petition, stating that "pursuant to [Commission] rules, the licenses canceled automatically" after NextWave had failed to make its first payment. ${ }^{53}$ NextWave immediately challenged the FCC's decision before the D.C. Circuit.

The D.C. Circuit had a more restrictive view of the scope of the FCC's regulatory power in bankruptcy proceedings than the Second Circuit. It reversed the FCC's cancellation of NextWave's licenses, holding that although the FCC was a regulator, its canceling of the licenses had violated section 525(a) of Title 11 of the Bankruptcy Code. ${ }^{\text {st }}$ Section 525 (a) protects a person against discriminatory treatment by a governmental unit based solely on the fact that "such bankrupt or debtor is or has been a debtor." The D.C. Circuit found that it had jurisdiction to apply this section of the Code to the FCC, and

\footnotetext{
48 Id.

49 Id at 138.

50 See id at 139-40 ("The jurisdictional statutes leave no opening for the sort of jurisdiction over the FCC that the bankruptcy court seeks to exercise.").

51 Id.

52 Id at 141.

53 NextWave $v$ FCC, 254 F3d at 139.

54 Id at 130,155 (noting that the FCC chose a scheme that put it in a creditor-debtor relationship with the licensees).

5511 USC \$ 525(a) (1994).

56 The court asserted that its jurisdiction in this case arose from 47 USC $\$ 402$ (b): "Appeals may be taken from decisions and orders of the Commission to the United States Court of Appeals for the District of Columbia ... by the holder of any construction permit or station license which has been modified or revoked by the Commission." NextWave v FCC, 254 F3d at 140, quoting 47 USC $\$ 402$ (b).
} 
held that NextWave's litigation in the Second Circuit mandamus proceedings did not mean that res judicata barred NextWave's Bankruptcy Code arguments in the case before it. ${ }^{\text {s7 }}$

The D.C. Circuit held that the FCC had violated section 525 of Title 11 by canceling NextWave's licenses, ${ }^{58}$ because that section clearly and explicitly prohibits governmental units from canceling licenses for failure to pay a dischargeable debt: ${ }^{59}$ " $[\mathrm{A}]$ governmental unit may not ... revoke ... a license ... to ... a bankrupt ... solely because such bankrupt ... has not paid a debt that is dischargeable ... under this title.." The court held that the FCC could not escape this "provision's clear command simply because it acted for a regulatory purpose.",61 Nothing in section 525 or 362 states "that section 525 is subject to subsection 362(b)(4)'s regulatory power exception, or that the exception should be read to limit section 525's clear reach.," ${ }^{12}$

Under the Administrative Procedure Act, courts must "hold unlawful and set aside agency action ... found to be ... not in accordance with law [or] ... in excess of statutory jurisdiction, authority, or limitations." agency action not only if it conflicts with an agency's own statute, but also if it conflicts with another federal law.", The FCC's canceling of NextWave's licenses, the court found, conflicted with section 525 of Title 11. The court, relying on the Administrative Procedure Act, reversed the FCC's cancellation of NextWave's license. ${ }^{65}$

57 The court read the Second Circuit's decision as principally holding "that the Commission's license cancellation was a regulatory act reviewable only by a court of appeals under section 402 of the Communications Act, and thus that the bankruptcy court lacked jurisdiction to apply the Code to these acts." NextWave v FCC, 254 F3d at 143. With one exception, the D.C. Circuit did not understand the Second Circuit "to have decided as a substantive matter that nothing in the Bankruptcy Code prevents the Commission from canceling NextWave's licenses." Id.

The one exception the D.C. Circuit found was that issue preclusion barred NextWave from relitigating the question of whether the license cancellation falls within section $362(b)(4)$. Id at 148. The Second Circuit spoke "clearly and unequivocally about this issue." Id. Under the Second Circuit's jurisdictional reading of section 362, "this decision was necessary to the case: if subsection 362(b)(4) did not apply, section 362 could have provided a basis for the bankruptcy court to assert jurisdiction over the license cancellation." Id. Thus, in considering NextWave's Bankruptcy Code arguments, res judicata led the D.C. Circuit to "assume that the license cancellation" fell "within the regulatory power exception to the automatic stay." Id.

58 Id at 156.

59 Id at 150.

6011 USC \& 525(a).

61 NextWave v FCC, 254 F3d at 155-56.

62 Id at 150.

63 Id at 149, quoting 5 USC $\$ 706(2)$ (1994).

64 NextWave v FCC, 254 F3d at 149.

65 Id at $149,156$. 
Although the D.C. Circuit held that it was "a court of competent jurisdiction" ${ }^{\circ 5}$ and that the Bankruptcy Code invalidated the FCC's action, the court left open the issue of whether bankruptcy and district courts had jurisdiction to enforce this provision. Thus, the D.C. Circuit, looking at the same facts the Second Circuit had examined in NextWave, held that the FCC was subject to its jurisdiction and that the FCC's regulatory power was constrained by the Bankruptcy Code.

\section{The Fifth Circuit's GWI PCS Decision: The Bankruptcy and District Courts Have Jurisdiction over the FCC}

In GWI PCS, the Fifth Circuit took a narrower view of the FCC's regulatory power than both the Second and D.C. Circuits. The Fifth Circuit held that the FCC was subject to the jurisdiction of the bankruptcy and district courts. ${ }^{67}$ The court affirmed an avoidance judgment by the bankruptcy court that avoided more than 90 percent of GWI PCS's obligation to the FCC and allowed the subsidiary-debtors to retain the license. ${ }^{68}$ The Fifth Circuit upheld the district court's decision that the FCC's appeal was equitably moot and held that the bankruptcy court did not improperly assume the FCC's regulatory authority.

First, the Fifth Circuit held that the district court had jurisdiction to declare the FCC's challenge to the bankruptcy court's decision equitably moot, a "recognition by the appellate courts that there is a point beyond which they cannot order fundamental changes in reorganization actions." ${ }^{70}$ The Fifth Circuit stated that even if equitable mootness was inappropriate, the bankruptcy court acted within "its jurisdiction to preserve property of the estate and further the reorganization plan."1 In addition, the Fifth Circuit reasoned that 11 USC $\S 106$, which abrogates sovereign immunity, ${ }^{2}$ applies to both the United States and the FCC and thus both were subject to the bankruptcy proceedings. ${ }^{3}$

66 Id at 152.

67 GWI PCS, 230 F3d at 798 (finding the district court had appellate jurisdiction under 28 USC $\S 158(a)$ ); id at $804 \mathrm{n} 29$ (holding the bankruptcy court's act of enjoining the FCC from revoking the licenses and avoiding obligations under the notes was within its jurisdiction under 11 USC \& 541).

68 GWI PCS, $230 \mathrm{F3d}$ at 791 (affirming the bankruptcy court's avoidance of " $\$ 894$ million of the $\$ 954$ obligation to the FCC").

69 See id.

70 Id at 800 , quoting In re Manges, 29 F3d 1034, 1039 (5th Cir 1994).

71 Id at $803 \mathrm{n} 29$, citing 11 USC $\$ 541$ (1994).

7211 USC $\S 106$ (c) (1994) ("Notwithstanding any assertion of sovereign immunity by a governmental unit, there shall be offset against a claim or interest of a governmental unit any claim against such governmental unit that is property of the estate.").

73 See GWI PCS, 230 F3d at 804. 
Second, the court disagreed with the Second Circuit's conclusion that courts should defer to the FCC's interpretation "that under its regulations the binding obligation to pay the full bid prices attaches "upon the acceptance of the high bid.", ${ }^{74}$ The court instead argued that "where an agency's interpretation occurs at such a time and in such as [sic] manner as to provide a convenient litigation position for the agency," the court would-as it had in the past-decline to defer to the interpretation. ${ }^{75}$ Overall, the Fifth Circuit had a much more expansive view of the jurisdiction of courts over the FCC in bankruptcy proceedings than the Second or D.C. Circuits.

Differing interpretation of the FCC's role in bankruptcy proceedings is the key to this three-way circuit split. Confronting three largely identical fact patterns (two of which were exactly identical), the circuits have gone in dramatically different directions.

The Second Circuit has treated the FCC's decision to cancel NextWave's licenses as regulatory. Bankruptcy and district courts do not possess jurisdiction over the FCC in its regulatory capacity; such jurisdiction is vested by the Bankruptcy Code exclusively in federal appellate courts. When direct challenge was brought before the D.C. Circuit, that court, like the Second Circuit, treated the FCC as a regulator, but it struck down the FCC's decision to cancel the licenses as a violation of the Bankruptcy Code. The Administrative Proceeding Act, according to the D.C. Circuit, required it to set aside agency action in conflict with another federal law, namely, the Bankruptcy Code. Finally, the Fifth Circuit has held that bankruptcy and district courts do have jurisdiction over the FCC in a bankruptcy proceeding involving a licensee, because the bankruptcy courts have jurisdiction over the property of a debtor in bankruptcy and the district courts then have appellate jurisdiction. Different understandings of the extent of the FCC's role in bankruptcy proceedings drove each result. Thus, finding the appropriate role for the FCC in licensee bankruptcy proceedings would resolve this three-way split.

\section{THE UNCLEAR ROLE OFTHE FCC IN BANKRUPTCY PROCEEDINGS}

In light of the FCC's ongoing auctioning of electromagnetic spectrum licenses to specialized groups of bidders and the ongoing contro-

74 Id at 806, quoting In re Applications for Assignment of Broadband Personal Communications Services Licenses, 14 FCC Rec 1126 (Dec 23, 1998).

75 Id at 807.

76 See Steven Lipin, Two Opposite Court Rulings Raise Questions about FCC's Next Move on NextWave Licenses, Wall St J C17 (Nov 2,2000) ("NextWave is out of luck, and [GWI PCS] is in fat city,' said [Professor] Douglas Baird. . . 'The sheer contrast of the two cases with similar facts is the kind of thing that gets the attention of the Supreme Court."') 
versy surrounding these auctions, the scope of the FCC's regulatory power in bankruptcy proceedings is likely to attract increasing attention. "The unclear nature of the FCC's regulatory power may lead to a number of legal, logistical, and distributional problems. This section examines how uncertainty over the FCC's regulatory power may create three significant problems: a flood of FCC bankruptcy cases in the D.C. Circuit, license distributional problems, and legal precedents that could allow other regulatory agencies to undermine the primary goal of Chapter 11 bankruptcy.

First, the D.C. Circuit could potentially be inundated with bankruptcy cases involving the FCC. In NextWave v FCC, the D.C. Circuit reasoned that the plain language of the statute, permitting appeal to the D.C. Circuit by "the holder of any ... station license which has been ... revoked by the Commission," included NextWave. ${ }^{78}$ If other circuits follow the Second Circuit's example and hold that the FCC is a regulator whose actions are only reviewable by the D.C. Circuit, bankruptcy cases would proceed directly from an FCC decision to an appeal to the D.C. Circuit. No bankruptcy or district court would be able to help licensee debtors restructure their debts to the FCC to retain their licenses. The FCC could cancel or revoke any licenses for which they could receive a better price from reauctioning or which the FCC believed could be put to better use by other, non-bankrupt firms rather than waiting for the debts to be restructured. ${ }^{\text {so }}$ The D.C. Circuit's already crowded schedule would be burdened by appeals by debtors in bankruptcy from all over the country whose licenses had been cancelled or revoked. ${ }^{81}$

Second, distributional problems could arise from continued uncertainty over the extent of the FCC's regulatory power. The FCC's

77 See, for example, Stephen Labaton and Simon Romero, FCC Auction Hit with Claim of Unfair Bids, NY Times A1 (Feb 12, 2001) (criticizing recent FCC auctions where large corporations colluded with small businesses to obtain licenses at reduced prices); Editorial, Flawed Wireless Auction, NY Times A30 (Feb 13, 2001) (criticizing recent FCC auctions of electromagnetic spectrum licenses that gave financial preferences to small businesses but allowed them to be financed by larger businesses).

78 NextWave v FCC, 254 F3d at 140, quoting 47 USC $\$ 403(b)(5)$ (1994). See also Mobile Communications Corp of America v FCC, 77 F3d 1399, 1403 (DC Cir 1996) (noting that the term "station license" in section 402(b) encompasses PCS licenses).

79 In re FCC, 217 F3d at 139-40 ("Section 402(b) is applicable to all appeals from the FCC's licensing actions ... judicial review of all cases involving the exercise of the Commission's radio licensing power is limited to the courts of appeals for the D.C. Circuit.").

so Lipin, Two Opposite Rulings, Wall St J at C17 (cited in note 76) (reporting that the FCC's decision to cancel and reauction NextWave's licenses has been criticized as a moneymaking scheme at odds with the FCC's goal of getting the spectrum up and running).

81 The D.C. Circuit could decide not to hear such cases based on efficiency cost concerns. However, the circuit might feel impelled to take these cases because if other circuits continued to hold that only the D.C. Circuit had jurisdiction and the D.C. Circuit declined to hear such cases, debtors would be left with no recourse from decisions by the FCC. 
financial interest in collecting its debt conflicts with the purpose of bankruptcy law. Rather than attempting to protect creditors and save jobs by preventing a rush on the bankrupt corporation's assets, ${ }^{82}$ the FCC could use its regulatory power to jump to the front of the creditor line.

The aftermath of the D.C. Circuit's NextWave decision reveals the distributional problems that can result from such behavior by the FCC. Shortly after winning In re FCC, the FCC reauctioned the licenses it had taken back from NextWave in the largest government auction ever. The licenses, which NextWave had previously won with bids of $\$ 4.74$ billion in 1996, were valued in 2001 at nearly $\$ 16$ billion. All that stood in the way of the winning bidders getting these licenses was the resolution of the NextWave case.

The D.C. Circuit's decision that the government had unfairly confiscated the NextWave's licenses sent regulators and the rest of the telecommunications industry reeling. ${ }^{24}$ The fates of the licenses and of NextWave remain unclear. Regulators and rival telecommunications companies still oppose the return of the licenses to NextWave, ${ }^{85}$ as do some federal policy makers who fear budget constraints. ${ }^{86}$ NextWave also faces the daunting task of finding new financing during a time of investor uncertainty.

Perhaps the group hurt most by the long-running NextWave battle has been American consumers, for whose benefit the FCC was created. ${ }^{87}$ As the airwaves have become more crowded, consumers demand better phone service and "increasingly find calls dropped or not completed, a problem that could have been greatly alleviated years ago had the licenses at stake here been put to use by now."

82 HR Rep No 95-595 at 220 (cited in note 7) (noting that the purpose of a Chapter 11 bankruptcy is to protect creditors and employees of the distressed firm).

83 Stephen Labaton and Riva D. Atlas, Against All Odds, a Telecom Rebirth, NY Times S1 (July 15, 2001) (detailing the names of bidders and the amounts of their bids in the FCC's reauction of NextWave's licenses).

84 Yochi J. Dreazen and Andrea Petersen, The Fate of NextWave's Licenses for Wireless Spectrum Is Unclear, Wall St J C1 (Jun 28, 2001) (describing the confusion in the telecommunications industry about which companies had the rights to NextWave's licenses after the D.C. Circuit's opinion in NextWave v FCC).

85 Labaton and Atlas, Against All Odds, NY Times at S1 (cited in note 83) (reporting on the reaction to the D.C. Circuit's decision that the licenses should be returned to NextWave).

86 Id (These policymakers "fear that NextWave's victory could blow a hole in the budget that would force Congress and the White House to violate their pledge not to dip into Medicare and Social Security."). See also John Harwood, Declining Revenue Raises the Stakes on Fall Budget Fights, Wall St J A1 (Aug 10,2001) (arguing that NextWave's court victory could cost the government billions, contributing to a downturn in the economy that might force a raid on the Social Security trust fund in 2002).

87 See Coase, $2 \mathrm{~J} \mathrm{~L} \mathrm{\&} \mathrm{Econ} \mathrm{at} 10$ (cited in note 2) (describing the purpose for which the FCC was created).

88 Labaton and Atlas, Against All Odds, NY Times at S1 (cited in note 83). See also Andrea 
The FCC has demonstrated that it may create economic inefficiencies when it is given power over bankruptcy proceedings. ${ }^{89}$ It is quite possible that if uncertainty about the scope of the FCC's regulatory power in bankruptcy continues, the FCC would repeat its previous distributionally inefficient behavior.

Third, this situation could create a precedent in other regulatory areas. If courts permit the FCC to use its regulatory power to gain advantage as a creditor, other regulatory agencies could draw on FCC cases as precedents to gain a similar advantage in bankruptcy proceedings. Such action could seriously undermine the express purpose of Chapter 11 bankruptcy ${ }^{\text {on }}$ in cases involving these agencies as creditors.

Thus, a solution is needed to clarify the role that courts will play in future bankruptcy proceedings in which it is both a creditor and a regulator. This solution should also guide the FCC toward more efficient regulation, protect debtor corporations and winning bidders in FCC auctions, and American consumers. The solution would also uphold the purpose of Chapter 11 in bankruptcies in which regulators are also creditors.

\section{The Role OF LAND USE REgUlatoRY AGENCIES IN BANKRUPTCY PROCEEDINGS}

Part of the problem in defining the FCC's role in bankruptcy proceedings stems from the fact that this is an issue of first impression for most courts. ${ }^{\text {I1 }}$ However, an answer can be found by adapting a solution that has been successfully implemented in the land use regulatory context. The role of a regulatory agency in bankruptcy proceedings should be limited to its regulatory competence: Agencies are competent to regulate how debtors use regulated resources, but bankruptcy courts have jurisdiction over the property of the debtor's estate."

The comparison between the FCC and land use regulators is particularly apt for three reasons. First, spectrum regulation may be com-

Petersen, That*\#)@* Cellphone!: Carriers Install Better Gear, Use Roving Fix-It Vehicles But Quality is Still an Issue, Wall St J B1 (July 23, 2001) (describing how the creation of new spectrum will help improve quality for an increasing number of cell phone users).

89 See David Wessel, Capital: The Strange Case of the Unused Spectrum, Wall St J A1 (Aug 9, 2001) (describing how the FCC's treatment of NextWave has led to economic inefficiencies which have hurt consumers, the telecommunications industry, and the government).

90 See HR Rep No 95-595 at 220 (cited in note 7) (explaining that the purpose of a Chapter 11 business reorganization case is to prevent a rush on a debtor's assets by creditors in order to preserve a firm's going-concern value so that creditors recover more of what they are owed, employees retain their jobs, and stockholders receive a return on their investment).

91 Prior to the FCC's adoption of the auction system in 1993, the FCC was rarely, if ever, a creditor in bankruptcy.

92 MCorp, 502 US at 40. 
pared to real property regulation because both deal with the efficient allocation of a scarce good that is subject to problems with interference. ${ }^{33}$ Second, the FCC is similar to a land use regulator because its goal is to guide the development of a resource so it is used in a manner that best serves the needs of the public and is economically efficient." Third, the FCC and land use regulation have followed a pattern of allowing increasingly liberal practices: strict restrictions on use, fixed primary use accompanied by flexible secondary uses, and semifungible use."

The following hypothetical provides a framework for investigating how the regulatory power of land use regulators is limited in bankruptcy proceedings. Town decides to privatize a municipal theater by auctioning it off to private investors. To encourage small entrepreneurs, Town agrees to finance much of the purchase price. Firm makes a winning bid of $\$ 11$ million for the theater, pays a $\$ 1$ million down payment and promises to pay the balance over a number of years. Firm borrows an additional $\$ 10$ million and uses it to buy equipment. Unfortunately, there is an economic downturn and the theater is less popular than expected. Firm cannot pay obligations to Town and other creditors. It files a Chapter 11 petition. Firm is insolvent. It owes $\$ 20$ million, but is worth only $\$ 15$ million. Two guiding principles define Town's regulatory power in the subsequent bankruptcy proceedings. First, debtors in bankruptcy are subject to the law. Second, debtors should not be penalized because they are in bankruptcy.

First, Firm, as a debtor in bankruptcy, still must obey the law. The theater is property of the estate under section 541(a) of the Bankruptcy Code. ${ }^{36}$ Firm's property comes into the bankruptcy estate subject to all its nonbankruptcy limits, including limits on safety and use." A developer does not lose her building permit just because she has filed for bankruptcy under section 525(a), but building inspectors can

93 See Leo Herzel, My 1951 Color Television Article, 41 J L \& Econ 521. 524 (1998) (describing development of author's idea to auction the spectrum: "The main specific problem I had in mind was the efficient allocation of space in busy streets of large cities, 24 hours a day, 7 days a week, to eliminate the combination of crowding and underuse that still persists."); Coase, 2 J L \& Econ at 27-28 (cited in note 2) (analogizing frequency use to other private property rights).

94 See Coase, $2 \mathrm{~J} \mathrm{~L} \&$ Econ at 10 (cited in note 2) (explaining that the FCC was established efficiently to regulate the spectrum for the benefit of the American public).

95 See Robert C. Ellickson and A. Don Tarlock, Land Use Controls: Cases and Materials 362-63 (Little, Brown 1981) (describing the evolution of land use planning from long-range, end-state planning to flexible, middle-range planning).

96 See 11 USC $\$ 541$ (a) (defining property of the debtor under Bankruptcy Code).

97 See Chicago Board of Trade v Johnson, 264 US 1, 14-15 (1924) (holding that a debtor is in possession of a membership in the Chicago Board of Trade and the bankruptcy court could thus order its transfer, subject to rules already in place before owner became bankrupt); In re Javens, 107 F3d 359, 370-71 (6th Cir 1997) (holding that exception to automatic stay provided by section $362(b)(4)$ is not limited to nondestructive exercises of government power). 
prevent further building and can even have a building torn down if it does not meet building codes. Similarly, Town could condition Firm's building permit or liquor license on actual use and have the permit or license lapse when no longer used. ${ }^{\text {ss }}$

Second, Firm should not be penalized because it is in bankruptcy. Town cannot provide that the lease is forfeited in the event of bankruptcy." Forfeiture provisions in the event of bankruptcy are prohibited by the Bankruptcy Code because they undermine bankruptcy policy by destroying the firm's going-concern value. ${ }^{100} \mathrm{~A}$ theater company without a theater has little value (assuming no other municipality is offering a new theater). Thus, the Bankruptcy Code protects debtors from being penalized just because they have filed for bankruptcy.

The Bankruptcy Code honors creditors' rights, but in a manner that ensures that Firm survives if it is economically viable apart from its problems with its creditors. There is a difference between closing down Firm because the theater is unsafe and closing it down because doing so allows one creditor to gain an advantage over another. In the hypothetical, Town decided to finance the winning theater bidder. Having done this, Town must live with the consequences. It can continue to regulate the use of the theater, but as far as trying to collect what is owed, Town is a creditor.

If Town does not think the theater is being put to its highest value use while Firm is in bankruptcy, Town cannot take back the theater. For example, if Firm is running sparsely-attended dinner theater Shakespearean tragedies and Town believes the community would be better served by another company which would bring in Broadway musicals, Town cannot use its regulatory power to reclaim the theater. $^{101}$

98 See In re Gull Air, Inc, 890 F2d 1255, 1263 (1st Cir 1989) (holding that because licensee's rights in the landing slots would have ceased automatically, withdrawal of those slots by the FAA did not constitute an administrative act or proceeding within the purview of section 362(a)); In re Yellow Cab Co-op Assn, 132 F3d 591, 593 (10th Cir 1997) (holding that the Colorado Public Utilities Commission's decision not to allow the transfer of 300 of 600 operating certificates by a bankrupt taxicab company, because the certificates had become dormant through nonuse, was a valid exercise of its regulatory power that was exempt under section 362(b)(4)-(5) from the automatic stay provisions of the Bankruptcy Code).

99 See 11 USC $\S 541(\mathrm{c})(1)$ (stating that an interest of the debtor in property becomes property of the estate notwithstanding any provision in an agreement, transfer instrument, or applicable nonbankruptcy law that restricts transfer of such interest by the debtor; or is conditioned on the insolvency or financial condition of the debtor).

100 See id.

101 A similar situation arises in the liquor license context. If Firm has a liquor license to run a bar at the theater, Town can regulate the use of this license but cannot take it away just because Firm has filed for bankruptcy. Courts have held that state and municipal liquor license regulators can exercise their regulatory power over debtors in bankruptcy. This includes suspension or revocation of liquor licenses in order to protect the public's health and safety under section 362(b)(4). See Vaspourakan, Ltd v Licensing Bd for Boston, 85 BR 189, 189 (D Mass 1988) 
In light of these two guiding principles, Town's position as creditor should be determined by its prepetition actions rather than by its role as a regulator. Town will argue that it should have priority over other creditors. However, Town should only have priority if it bargained for it and complied with nonbankruptcy rules governing the creation of a security interest in personal property. ${ }^{102}$ If Town followed this path and took an interest in all assets of Firm, it would be entitled to $\$ 10$ million. As a fully secured creditor, Town is entitled to the value of the theater, but not to the theater itself..$^{103}$ Firm's going-concern value and the jobs it provides would be destroyed if Town were allowed to take back the theater. Town would benefit at the expense of Firm's other creditors, thereby defeating one of the main purposes of Chapter 11 bankruptcy: to prevent a rush on a debtor's assets in order to preserve a firm's going-concern value. ${ }^{104}$

Town should be treated as a general creditor if it did not take a security interest. ${ }^{105}$ All creditors receive seventy-five cents on the dollar because Firm owes $\$ 20$ million and has assets of $\$ 15$ million. In this case, Town should receive a note worth $\$ 7.5$ million. ${ }^{105}$

(holding that bankruptcy court cannot "interfere" with a licensing board's legitimate use of its police power in shutting down an establishment for violations of state law); In re Arnage, Inc, 33 BR 662, 665 (Bankr E D Mich 1983) (holding that under section 362(b)(4) a state liquor commission did not violate automatic stay by canceling liquor license where trustee failed to request extension of license); Colonial Tavern, Inc v Byrne, 420 F Supp 44, 45 (D Mass 1976) (holding that the bankruptcy court was without jurisdiction to grant a preliminary injunction enjoining the city licensing board from enforcing a sixty-day suspension of liquor licenses held by Chapter 11 debtors for alleged violations of a midnight closing hour because such action with within the board's regulatory power). However, courts have often not allowed states and municipalities to advance their interests as creditors in bankruptcy under section 362(b)(4). See In re Hoffman, 65 BR 985, 993 (Bankr D RI 1986) (holding that state tax administrator's attempt to block trustee's sale of debtor's liquor license until debtor had paid all delinquent taxes, as provided by state statute, did not fall within the exception provided by section $362(\mathrm{~b})(4)$ because the state was acting for a pecuniary purpose); In re Addis, 40 BR 908, 909-10 (Bankr W D Wis 1984) (finding that automatic stay prevents state from refusing to grant liquor license on basis of outstanding debts; such action constitutes state action in pecuniary interest of creditor, not enforcing enforcement of regulatory law). In addition, various bankruptcy and district courts have held that section 525 can prevent regulatory agencies from revoking licenses when such action discriminates against bankrupts, even when the automatic stay does not apply. See, for example, In re William Tell II, Inc, 38 BR 327, 330 (N D Ill 1983) ("Even if a state proceeding is not automatically stayed, a bankruptcy court has authority to enjoin certain conduct under 11 USC $\$ 525$."). Thus, Town has the power to control how Firm uses its liquor license but cannot take back the license in order to advance its interest as a creditor or just because Firm has filed for bankruptcy.

102 See generally UCC art $9(2000)$ (covering secured transaction sales of accounts and chattel paper).

103 See 11 USC $\$ 506$ (a) (1994) ("An allowed claim of a creditor secured by a lien on property in which the estate has an interest ... is a secured claim to the extent of the value of such creditor's interest in the estate's interest in such property.").

104 See HR Rep No 95-595 at 220 (cited in note 7) (explaining the purpose of a Chapter 11 business reorganization case).

10511 USC $\$ 502$ (1994).

106 Entrepreneur's equity stake is eliminated, and it can only remain the owner of the eq- 
Land use regulators are competent to regulate the way real property is used in bankruptcy. However, invading the jurisdiction of bankruptcy courts to advance their interests as creditors is beyond their regulatory competence. Thus, land use regulators' regulatory competence both defines and limits the scope of their regulatory power in bankruptcy proceedings.

\section{THE FCC'S ROLE IN BANKRUPTCY SHOULD BE LIMITED TO ITS REGULATORY COMPETENCE}

The NextWave and GWI PCS cases share the same fundamental issues as the theater land use regulation case. This Part proposes a novel solution to the split between the Second, Fifth, and D.C. Circuits, borrowing from the examples of the limitations of other regulatory agencies in bankruptcy. Issues of jurisdiction in bankruptcy proceedings involving the FCC should turn on regulatory competence. This Part explores how courts have employed this solution with a wide range of agencies and how this solution is in accord with the Bankruptcy Code. It then shows how the solution can be applied to the FCC.

\section{A. Regulatory Competence:Two Guiding Principles for Bankruptcies Where Regulatory Agencies are Creditors}

Divided interests arise in many situations in which a regulatory agency is a creditor in a bankruptcy proceeding. Agencies must separate their role as regulator from their role as creditor in many contexts. For example, agencies have dual roles in situations as diverse as building permits granted by local governments and landing slots issued by the FAA. ${ }^{107}$ A guideline for making this separation is to limit the jurisdiction of regulatory agencies in bankruptcy proceedings to matters in which the agencies have regulatory competence. ${ }^{103}$

Many courts adhere to the two basic principles articulated in the theater hypothetical in order to determine the regulatory competence of an agency that is a creditor in a bankruptcy proceeding: (1) debtors in bankruptcy are subject to the law, but (2) debtors should not be penalized because they are in bankruptcy.

uity if it adds new value and shows it is paying market rates for it. See Bank of America $v 203$ North LaSalle Street Partnership, 526 US 434, 437, 457-58 (1999) (holding that a pre-bankruptcy equity holder is prohibited from contributing new capital or receiving new ownership interests in a reorganized entity solely on account of his prior interest and must pay market rates for the new interest). Forfeiture is prevented to preserve going-concern value and jobs, not to protect the interests of equityholders.

107 See In re Gull Air, Inc, $890 \mathrm{~F} 2 \mathrm{~d}$ at 1263.

108 See Parts III.B and IV. 
1. Debtors in bankruptcy are subject to the law.

First, debtors in bankruptcy must obey the law, including regulations pertaining to the operation of the business. ${ }^{109}$ For example, a bankrupt taxi firm must continue to comply with all the rules governing taxi use. A town may limit the taxi's hours of operation and require installation of safety equipment, even if costly. It may also condition the continued existence of taxicab medallions on actual utilization and have them lapse if not used. ${ }^{110}$ Similarly, if a municipal government condemns the debtor's property as unsafe, it can demolish it even though the debtor is in bankruptcy."

Under section 362(b)(4) of the Bankruptcy Code, the government is able to tell a debtor to stop operating in violation of a state or federal statute. ${ }^{112}$ Section $362(b)(4)$ provides that the automatic stay ${ }^{113}$ does not apply to "the commencement or continuation of an action or proceeding by a government unit ... to enforce such governmental unit's ... police and regulatory power." ${ }^{\text {,14 }}$ The firm cannot avoid spending money to comply with government orders just because it is in a collective proceeding. ${ }^{115}$

However, section 362(b)(4) also limits the actions regulatory agencies can take against debtors in bankruptcy. Section 362(b)(4) requires courts to draw a line between the actions the government unit takes in the exercise of its regulatory power and those it takes as an ordinary prepetition creditor. ${ }^{116}$ This line is not easy to draw because the government can argue that any action it takes is for a regulatory purpose. An action may still be regulatory even though a debtor must spend money in order to comply."

109 See Pub L No 95-598, 92 Stat 2667, codified at 28 USC \$ 959(b) (1994) ("[A] trustee ... including a debtor in possession, shall manage and operate the property in his possession ... according to the requirements of the valid laws of the State in which such property is situated.")

110 In re Yellow Cab, $132 \mathrm{~F} 3 \mathrm{~d}$ at 593.

111 See In re Javens, 107 F3d 359, 370-71 (6th Cir 1997) (holding that the Bankruptcy Code does not prevent cities from sending bulldozers to enforce building condemnation laws and that the automatic stay provided for by 28 USC $\$ 362$ (a) does not prevent such action).

112 See 11 USC \& 362(b)(4).

113 See 11 USC $\$ 362$ (a) (stating that the automatic stay forces the general creditors of an insolvent debtor to wait until the bankruptcy proceeding has ended before they can collect what is owed to them and also gives the bankruptcy court control over the assets of the estate).

11411 USC \& 362(b)(4).

115 See Baird, Bankruptcy at 200 (cited in note 8) ("All agree that debtors in bankruptcy have to play by the same rules as everyone else... If a debtor is operating in violation of a state or federal statute, the government should be able to tell it to stop.").

116 Id. A prepetition creditor is an entity that has a claim against the debtor that arose at the time of or before the order for relief concerning the debtor. 11 USC $\$ 101(10)(A)$ (1994).

117 See Baird, Bankruptcy at 200 ("Spending money to comply with government orders is not one of the things that a firm should be able to avoid.... All agree that $\S 362(\mathrm{~b})(4)$ ensures that the government retains this power notwithstanding the automatic stay."). 
In MCorp, the Supreme Court created a rough guide to the extent to which agencies can exert their regulatory power over debtors in bankruptcy under section 362(b)(4): Regulators have the power to control the use of regulated resources, but bankruptcy courts have jurisdiction over the property of the debtor's estate. ${ }^{118}$ Courts have acted in this gray area to uphold the ability of agencies to exercise their regulatory powers but have also reined in agencies that have tried to use their power to gain an advantage as prepetition creditors.

A broad range of regulatory agencies have been affected by these rulings, including agencies that regulate land use, drivers' licenses, the environment, and labor. Bankruptcy judges do not have authority to interfere with the operation of land use ${ }^{119}$ regulations when government units are properly acting in their regulatory capacity. Likewise, driver's license regulators can enforce regulations against debtors ${ }^{120}$ but cannot use their regulatory position to advance their interests as creditors. ${ }^{121}$ Similarly, Occupational Safety and Health Act ("OSHA") rules and environmental regulations remain enforceable as long as agencies act as regulators rather than as creditors. ${ }^{122}$ Also, Environ-

118 See MCorp, 502 US at $40-41$.

119 See US Department of Housing \& Urban Devolopment $v$ Cost Control Marketing \& Sales Management of Virginia, Inc, 64 F3d 920, 927-28 (4th Cir 1995) (holding that action by Department of Housing and Urban Development against corporate officers of real estate company was regulatory in nature, and therefore was allowed under 11 USC \& 362(b)(4), despite the automatic stay). See also United States v Energy International, Inc, 19 BR 1020, 1021 (S D Ohio 1981) (finding action by United States to collect civil penalty for numerous violations of Surface Mining Control and Reclamation Act of 1977 to be regulatory in nature and therefore excepted from stay under 11 USC \& 362(b)(4)); Cournoyer v Lincoln, 790 F2d 971, 977 (1st Cir 1986) (holding that provisions of 11 USC $\$ 362$ (b)(4) and (5) exempt from automatic stay township's enforcement of zoning ordinance in Chapter 11 proceeding).

120 Numerous courts have held that section 362(b)(4) does not preclude these agencies from "issuing traffic citations ... determining guilt or innocence of driver," issuing summonses, imposing fines, and suspending or revoking licenses or taking any other actions towards debtors in bankruptcy necessary to protect public health and safety. In re Colon, 102 BR 421, 428 (Bankr E D Pa 1989). See also In re Norton, 76 BR 624, 631 (Bankr M D Tenn), affd, 84 BR 119 (M D Tenn 1988), revd on other grounds (6th Cir 1989) (holding revocation of Chapter 13 debtor's license by Tennessee Department of Safety following automobile accident involving debtor is excepted from automatic stay as exercise of state's police powers).

121 Section 362(b)(4) has been held not to allow these agencies to enforce collection of fines by "revoking or threatening to revoke driving privileges or by threatening arrest" of debtors in bankruptcy and collection of fines is subject to section 362(a)'s automatic stay. See Colon, 102 BR at 428. See also In Re Bill, 90 BR 651, 656-57 (Bankr D NJ 1988) (holding that although imposition of New Jersey merit rating plan surcharge is action to enforce department of motor vehicles' regulatory power within the meaning of 11 USC $\$ 362(\mathrm{~b})(4)$, collection of surcharge imposed as a result of prepetition conviction is stayed); In re Kuck, 116 BR 821, 824-25 (Bankr S D Ala 1990) (holding that action by state Department of Safety in requiring filing of police report was not an exercise of police power protected from an automatic stay).

122 See New York v Exxon Corp, 932 F2d 1020, 1025 (2d Cir 1991) (holding that government suits under CERCLA for recovery of costs incurred in responding to violations of the statute fall under police-power exception to automatic stay); In re Commerce Oil Co, 847 F2d 291, 297 (6th Cir 1988) (holding that initial proceedings to fix civil fines and penalties against Chapter 11 
mental Protection Agency ("EPA") enforcement actions ${ }^{123}$ and Fair Labor Standards Act proceedings ${ }^{124}$ are not barred when agencies follow similar guidelines. However, the Supreme Court in Ohio v Kovacs held that the automatic stay enjoins actions where agencies have used their regulatory power to advance their position as creditors. ${ }^{125}$

\section{Debtors should not be penalized because they are} in bankruptcy.

Second, courts also follow the guiding principle that debtors should not be penalized because they are in bankruptcy. Bankruptcy does not necessarily change a debtor's property rights. ${ }^{126}$ Section 525 of Title 11 protects individuals and corporations who are or have been in bankruptcy from discriminatory treatment by governmental units and private employers. ${ }^{127}$ Specifically, governmental units may not "revoke, suspend, or refuse to renew a license, permit, charter, franchise, or other similar grant ... to ... a bankrupt ... solely because such bank-

debtor for violations of Tennessee Water Quality Control Act are within police-power exception to automatic stay under 11 USC \& 362(b)(4)); Brock v Morysville Body Works, 829 F2d 383, 38890 (3d Cir 1987) (holding that OSHA request for fully prospective order abating postpetition safety violations endangering Chapter 11 debtor's employees at manufacturing plant is exempt from stay, but summary enforcement of money judgment is not fully prospective and is therefore subject to stay); In re Allied Mechanical Services, Inc, 38 BR 959, 962-63 (Bankr N D Ga 1984) (holding that claim against debtor brought by Secretary of Labor did not violate automatic stay where Secretary did nothing more than fix amount of penalty for debtor's violation of OSHA).

123 See Commonwealth Oil Refining Co, Inc v United States Environmental Protection Agency, 805 F2d 1175, 1188 (5th Cir 1986) (holding EPA's enforcement action under the Resource and Recovery Act to terminate Chapter 11 debtor hazardous waste facility's interim permit is not barred by automatic stay of section $362(\mathrm{a})$ ).

124 See Brock v Rusco Industries, Inc, 842 F2d 270, 273 (11th Cir 1988) (holding that action by federal government against Chapter 11 debtor under Fair Labor Standards Act and subsequent enforcement procedures is not barred by automatic stay since such action is in exercise of government's police power); Martin v Safety Electric Construction Co, 151 BR 637, 639 (D Conn 1993) (holding that Department of Labor action against Chapter 11 debtor claiming violations of FLSA is exempt from automatic stay because action was an exercise of the government's regulatory power and were not designed to advance government's pecuniary interest). But see Chao $v$ Hospital Staffing Services, Inc, 270 F3d 374, 388-89, 394 (6th Cir 2001) (holding that "hot goods" action brought by Secretary of Labor under the Fair Labor Standards Act, to prevent trustee of bankrupt employer's Chapter 7 estate from transporting in interstate commerce records that employer's staff had produced, during last weeks of employer's existence, without being compensated did not come within "police or regulatory power" exception to automatic stay and could be pursued in nonbankruptcy forum only if Secretary first obtained relief from stay).

125469 US 274, 285 (1985) (holding that affirmative duty to pay in order to clean up hazardous waste site was enjoined by automatic stay).

126 See Butner v United States, 440 US 48, 55 (1979) ("Property interests are created and defined by state law. Unless some federal interest requires a different result, there is no reason why such interests should be analyzed differently simply because an interested party is involved in a bankruptcy proceeding.").

127 See 11 USC $\S 525$ (providing that the government may not discriminate against or deny rights to a person who is or has been a bankrupt or debtor). 
rupt ... has been a debtor under this title or ... has not paid a debt that is dischargeable ... under this title."128

Thus, agencies should be excepted from the automatic stay only to the extent of their regulatory competence. The next Section examines how this solution can be applied to the FCC.

\section{B. Applying the Two Guiding Principles to Bankruptcies Where the FCC Is a Creditor}

The FCC wears two different hats in licensee bankruptcy proceedings: that of a regulator and that of a creditor. One of the most established bankruptcy principles is that debtors in bankruptcy continue to be bound by the rules that govern their ongoing operations. ${ }^{129}$ All of the FCC's rules controlling the use of licenses should have effect in bankruptcy. The FCC has this right under section 362(b)(4) of the Bankruptcy Code; the exercise of police and regulatory powers is exempted from the automatic stay. ${ }^{130}$ Just because a licensee is in bankruptcy, it should not be exempt from regulation by the FCC. If bankrupt licensees were not subject to regulation, they could disrupt the FCC's regulation of the spectrum. One of the FCC's primary purposes is to regulate use of electromagnetic spectrum licenses. ${ }^{131}$ Therefore, regulating license use by bankrupt licensees is clearly within the FCC's regulatory competence and should be allowed by courts.

Second, the FCC also wears the hat of a prepetition creditor. Its transactions with NextWave and GWI PCS involved the issuance of licenses in return for promissory notes. The FCC, as an entity owed a fixed sum, should be treated the same as any other creditor in the bankruptcy process. The FCC should not be allowed to argue that it is beyond the jurisdiction of the bankruptcy court when it comes to enforcing a promissory note. Serious logistical problems and economic inefficiencies would result from the courts' inability to subject the FCC to bankruptcy jurisdiction.

Deciding matters in a bankruptcy proceeding is beyond the FCC's regulatory competence for two reasons. First, enforcing a promissory note should not be seen as a regulatory action exempted from the automatic stay by section 362(b)(4). The Second Circuit in NextWave characterized the FCC's action revoking NextWave's li-

12811 USC $\$ 525(\mathrm{a})$.

129 See 28 USC $\$ 959$ (b) (1994) (stating that debtors in bankruptcy are still bound by nonbankruptcy laws).

130 See 11 USC $\S 362(b)$ (4) (exempting the exercise of authority to enforce a governmental unit's police and regulatory power from the automatic stay).

131 See 47 USC \& 151 (1994) (creating the FCC for the purpose of regulating interstate and foreign communication by wire and radio); 47 USC \$ 309 (1994) (giving the FCC the authority to license the spectrum). 
censes as regulatory because the FCC made full and timely payment of the winning bid "a regulatory condition for obtaining and retaining a spectrum license." ${ }^{\text {,132 }}$ Although this action may have been regulatory in name, it does not have to do with actual use of the electromagnetic spectrum. Instead, it is an effort by the FCC to gain an advantage as a creditor that courts should not allow. There is no mention in the Federal Communications Act of the FCC's being able to use its regulatory power to enforce promissory notes. ${ }^{133}$ In addition, legislative history shows that the section was meant to help agencies pursue their regulatory missions, not improve their positions as creditors. ${ }^{14}$ This type of action by the FCC should not be exempted from the automatic stay.

Second, even if the FCC can justify actions to enforce a promissory note as regulatory actions protected by section 362(b)(4), FCC cancellation of licenses should be prohibited as a violation of section 525. Section 525 prohibits governmental units, for whatever reason, from canceling licenses solely for failure to pay a debt dischargeable in bankruptcy. ${ }^{135}$ Under the Administrative Procedure Act, courts must invalidate agency action if it conflicts with another federal law. ${ }^{136}$ The Act thus restricts the regulatory actions that the FCC is competent to take under federal law. The FCC's actions to enforce promissory notes by canceling licenses of bankrupt licensees should be prohibited because they conflict with other federal law. Such a conflict puts canceling the licenses of debtors in bankruptcy beyond the FCC's regulatory competence. This lack of competence should subject the FCC to the jurisdiction of bankruptcy and district courts in cases where the FCC cancels the licenses of bankrupt licensees. The FCC took a security interest in the licenses ${ }^{137}$ and should rely on this interest in the same way as any other secured creditor, rather than trying to use its position

132 NextWave, $200 \mathrm{~F} 3 \mathrm{~d}$ at 52.

133 See 47 USC $\$ 307$.

134 See S Rep No 95-989, 95th Cong 2d Sess 52 (1978), reprinted in 1978 USCCAN 5838 (discussing the reasons for granting an automatic stay); HR Rep No 95-595 at 343 (stating that where an agency "is suing a debtor to prevent or stop violation of fraud, environmental protection, consumer protection, safety, or similar police or regulatory laws, or attempting to fix damages for violation of such a law, the action or proceeding is not stayed under the automatic stay.").

13511 USC $\$ 525(\mathrm{a})$.

1365 USC $\$ 706(2)$ (1994).

137 See Nextwave v FCC, 254 F3d at 134 ("[T]he Commission granted NextWave its licenses, took a security interest in each, and filed UCC financing statements to perfect its claims."); In re GWI PCS, 230 F3d at 809-11 (stating that GWI PCS had to give the FCC a security interest in the licenses). See also Wireless Telecommunications Bureau Announces Grant of Broadband Personal Communications Services Entrepreneurs' C Block Licenses to GWI PCS Inc, 12 FCC Rcd 1215, 1997 WL 28957 (Jan 27, 1997) ("GWI PCS will receive its individual BTA licenses following payment for each license of the final down payment and execution and return of the note and security agreement."). 
as a regulator to escape the bankruptcy court's jurisdiction and cut to the front of the line of creditors.

In the future the FCC could avoid the distributional problem it encountered with NextWave and accomplish its goal of more quickly moving licenses from a licensee who is not actually using its licenses to a new user by including a "use it or lose it" requirement in the contracts it makes with licensees. This requirement would allow the FCC to condition the continued existence of licenses on actual utilization and would provide that licenses would lapse when no longer used. ${ }^{138}$ It would also allow the FCC to accomplish its goal of more quickly moving licenses from licensees who are not using their licenses to new users. The automatic stay would not have any effect on the exercising of such a "use it or lose it" provision as long as the FCC would exercise it regardless of whether the licensee was in bankruptcy and whether it owed the agency any money. ${ }^{139}$ In this way, the FCC could accomplish its goal of allocating licenses to licensees who would put them to use while respecting the bankruptcy court's jurisdiction over the bankruptcy estate.

This solution, in addition to being viable, as shown by the land use example, would also prevent a serious threat to Chapter 11 bankruptcies involving regulatory agencies. The FCC defeats the purpose of Chapter 11 bankruptcy and creates economic inefficiencies when courts allow it to use its regulatory power to gain an advantage as a creditor. As was the case with NextWave, the FCC destroys a bankrupt telecommunications firm's going-concern value by taking away the firm's licenses, in contravention of the purpose of bankruptcy. It takes possession of the firm's most valuable assets, and other creditors,

138 See In re Gull Air, $890 \mathrm{~F} 2 \mathrm{~d}$ at 1263; In re Yellow Cab, $132 \mathrm{F3d}$ at 593. But see In re NextWave Personal Communications Inc, 244 BR 272 (Bankr S D NY 2000) ("NextWave VI") ("[T]here is substantial authority holding that regulatory provisions which interfere with property of a debtor's estate, even by "automatic" operation of the regulation, violate the automatic stay. ... Under this authority, an FCC regulation effecting automatic cancellation of a debtor's property rights by reason of any default would itself violate the automatic stay."); In re American Central Airlines, Inc, 52 BR 567, 569-71 (Bankr N D Iowa 1985) (holding, with respect to administrative action to reallocate FAA landing slots, that " $[t]$ he mere fact that an interest exists by the grace of government no longer precludes the interest from being treated as a property right," and "any act to enforce this [use it or lose it] contractual provision against the Debtors will constitute an act to obtain possession of property of the estate and an attempt to exercise control over property of the estate," and an "unlawful act" in violation of 11 USC § 362(a)(3)); In re National Cattle Congress, Inc, 179 BR 588, 597 (Bankr N D Iowa 1995) ("[R]egulatory provisions in direct conflict with control of the property [of the debtor's estate] by the Bankruptcy Court violate the automatic stay.").

139 See Douglas G. Baird, Thomas H. Jackson, and Barry E. Adler, Bankruptcy: Cases, Problems, and Materials 120 (Foundation 3d rev ed 2001) ("[T]he bankruptcy judge would have no power to second-guess the agency's revocation of a license based upon nonuse."). 
who are not able to jump to the head of the creditor line, receive less than they would if the firm remained a going-concern."

With the FCC as precedent, other regulatory agencies might try to achieve a similar advantage in Chapter 11 proceedings. Chapter 11 cases involving regulatory agencies as creditors could potentially devolve into judicial proceedings that destroy going-concern value, allowing agencies to jump to the front of the creditor queue.

By having the FCC's role in bankruptcy proceedings turn on regulatory competence, courts could prevent a slide down this slippery slope. The effectiveness of Chapter 11 bankruptcies involving the FCC would be preserved because the FCC would not be allowed to make an end run around the protections of the Bankruptcy Code. Other regulatory agencies would not be able to draw on FCC precedent to defeat the purpose of Chapter 11 bankruptcy. Thus, the solution of having the FCC's role in bankruptcy proceedings turn on regulatory competence is both viable and would produce significant benefits.

\section{CONCLUSION}

The jurisdiction of the FCC in bankruptcy proceedings should be defined by its regulatory competence. The FCC is competent to regulate use of the electromagnetic spectrum by bankrupt licensees, and bankruptcy and district courts should respect the FCC's jurisdiction in this area. However, enforcing promissory notes against debtors in bankruptcy is beyond the FCC's regulatory competence. The FCC, like all other prepetition creditors, should be subject to the jurisdiction of bankruptcy and district courts in matters relating to the collection of debts from debtors in bankruptcy.

140 Admittedly, "use it or lose it" provisions destroy a firm's going-concern value. However, the FCC would be acting in a regulatory capacity, in accord with a pre-petition licensing condition which does not require an affirmative act or decision, and would be furthering the Bankruptcy Code's goal of allowing governmental units to enforce their regulatory power. 